\title{
Direct Interaction of KIF5s and Actin-Based Transport Motor, Myo9s
}

\author{
Dae-Hyun Seog*
}

Departments of Biochemistry, College of Medicine, Inje University, Busan 614-735, Korea

Received May 12, 2011 /Revised July 6, 2011 /Accepted July 12, 2011

\begin{abstract}
Microtubule-based kinesin motor proteins are used for long-range vesicular transport. KIF5s (KIF5A, KIF5B and KIF5C) mediate the transport of various membranous vesicles along microtubules, but the mechanism behind how they recognize and bind to a specific cargo has not yet been completely elucidated. To identify the interaction protein for KIF5B, yeast two-hybrid screening was performed and a specific interaction with the unconventional myosin Myo9b, an actin-based vesicle transport motor, was found. The GTPase-activating protein (GAP) domain of Myo9s was essential for interaction with KIF5B in the yeast two-hybrid assay. Myo9b bound to the carboxyl-terminal region of KIF5B and to other KIF5 members. In addition, glutathione $S$-transferase (GST) pull-downs showed that Myo9s specifically interact to the complete Kinesin-I complex. An antibody to KIF5B specifically co-immunoprecipitated KIF5B associated with Myo9s from mouse brain extracts. These results suggest that kinesin-I motor protein interacts directly with actin-based motor proteins in the cell.
\end{abstract}

Key words : Kinesin-I, molecular motors, actin, myosin

\section{Introduction}

Most of the proteins necessary for the synaptic terminals must be transported down the synaptic terminal after synthesis in the cell body. The proteins are conveyed in various kinds of membranous vesicles and protein complexes in the synaptic terminal [7]. In the axon and dendrites, microtubules are the major longitudinal cytoskeletal filament. KIFs move along microtubules tracks [4,31]. In the synaptic terminal, such as presynaptic terminals and postsynaptic spines, actin filaments form the major cytoskeletal architecture [7]. Actin filaments have a polarity: the growing end points to the plasma membrane in the synaptic terminal region. Mainly myosins convey the various membranous vesicles along actin filament [8].

The first kinesin motor, Kinesin-I, was identified as a major motor protein for vesicle and organelle movement in cells [4]. Kinesin-I is composed of two kinesin heavy chains (KHCs, also called KIF5s), which contain the amino (N)-terminal motor domain and the carboxyl (C)-terminal domain, as well as two light chains (KLCs), which bind to the KIF5s (KIF5A, KIF5B and KIF5C) stalk region [7,34]. KIF5A, KIF5C and KLC1 are enriched in neural tissues, whereas KIF5B and KLC2 are ubiquitously expressed. KIF5s form homodimers and heterodimers [7]. Thus, they are

*Corresponding author

Tel: +82-51-890-6974, Fax: +82-51-894-5801

E-mail : daehyun@inje.ac.kr though to have similar function. KIF5 binds KLCs through light chain-binding domains in the stalk and tail domains [21]. The N-terminal motor domain of KIF5s is responsible for the force-generating motor activity and for binding to microtubules [4]. The site of interaction with the cargo has been attributed to the C-terminal tail domain of KIF5s [26].

The identification of conserved protein-protein interaction motifs in the KIF5s tail domain provided additional evidence that KIF5s bind their cargos through protein-protein interaction $[8,26]$. New technological progress makes it possible to identify binding proteins and cargos, by the GST pull-down experiments or by using yeast two-hybrid system. With the use of these methods, several cargos and binding proteins have been identified such as mitochondria [29], glutamate receptor-interacting protein 1 (GRIP1) [26], mRNA/protein (mRNP) complex [9], SNAP25 [5], syntabulin [28], Snytaxin [5], $\beta$-dystrobrevin [8]. Cargo molecules that bind to the tetratricopeptide repeat (TRP) domain of KLC have also been identified such as c-jun $\mathrm{NH}_{2}$-terminal kinase (JNK)-interacting proteins (JIPs) are well characterized [3], amyloid- $\beta$ precursor protein (APP) [16]. Although an increasing number of cargos and binding proteins have been reported, not all components or functions have been revealed yet [8]. In addition, little is known about the regulation mechanism for KIF5s-cargo recognition and interaction. To improve the understanding of the role KIF5s in brain, using the yeast two-hybrid screens, we identified the unconventional myosin Myo9b, as a protein that directly 
interacts with KIF5s in brain.

\section{Materials and Methods}

\section{Plasmid constructs}

A previously described mouse KIF5B cDNA [29,34] was utilized as a template to amplify the region coding for amino acids 905-963 using the appropriate primers. The amplified fragment was subcloned into pGEM T-easy vector (Promega Corp, Madison, WI, USA). The fragment was then EcoRI, Xhd-restricted and subcloned into the EcoRI, Xhd site of pLexA (Clontech, Palo Alto, CA, USA). The C-terminal fragments of murine Myo9a (accession NM_173018.2) and Myo9b (accession NM_001142322.1) were amplified by reverse transcription (RT)-PCR from murine brain and cloned into pGEM T-easy vector. The Myo9a and Myo9b fragments were inserted into pJG4-5 (Clontech).

\section{Yeast two-hybrid screen}

The Matchmaker LexA two-hybrid system was used for screening according to the previously reported [10]. In brief, the EGY48/ p8op-lacZ yeast cells containing the KIF5B bait plasmid were transformed with the embryonic murine brain cDNA library [10] and grown on synthetic dextrose (SD) plates supplemented with glucose but with no histidine, tryptophan, or uracil (SD/-His/-Trp/-Ura). The selection of positive clones was performed on X-gal plate. Library inserts were analyzed by restriction digestion. Library plasmids were tested for interactions of the reporter gene in yeast by the retransformation. Unique inserts were sequenced and DNA sequence analysis was performed with the BLAST algorithm at the National Center for Biotechnology Information (NCBI).

\section{$\beta$-Galactosidase activity in liquid cultures of yeast}

The strength of the interactions between Myo9b and KIF5s was assessed by measuring the $\beta$-galactosidase activity. The $\beta$-galactosidase activity of yeast was assayed as described previously [10]. In brief, mid-log phase transformed yeast cells were collected and permeabilized with $0.1 \%$ sodium dodecyl sulphate (SDS) and chloroform. An excess amount of chromogenic substrate o-nitrophenyl- $\beta$ -D-galactoside was added in excess to this lysate, and the mixture was incubated at $30^{\circ} \mathrm{C}$, and then the reaction was stopped by increasing $\mathrm{pH}$ to 11 by the addition of $1 \mathrm{M}$ $\mathrm{Na}_{2} \mathrm{CO}_{3}$. The formation of the reaction product, o-nitro- phenol, was determined by measuring absorbance at $420 \mathrm{~nm}$ on a spectrophotometer and normalizing for the reaction time and the cell density.

\section{Co-immunoprecipitation and Western blot analysis}

Mouse brain lysate was prepared as previously described [26]. Mouse brains were homogenized in ice-cold homogenization buffer (0.32 M sucrose, $4 \mathrm{mM}$ HEPES, $\mathrm{pH}$ 7.3) supplemented with protease inhibitors. The mouse brain homogenate supernatant was centrifuged again at $12,000 \times g$ for $15 \mathrm{~min}$, and the resulting supernatant was saved. For immunoprecipitation, the brain lysate was diluted in the same volume of $2 \times$ binding buffer ( $50 \mathrm{mM}$ HEPES, $240 \mathrm{mM} \mathrm{KCl}$, $2 \mathrm{mg} / \mathrm{ml} \mathrm{BSA}, 0.2 \%$ Triton X-100, pH 7.4) and incubated with anti-KIFs antibodies [26] or with control IgG overnight at $4^{\circ} \mathrm{C}$, followed by precipitation with protein-A Sepharose (Amersham Pharmacia, Piscataway, NJ, USA). The beads were collected by brief centrifugation and washed three times with TBS-T (20 mM Tris-HCl, pH 7.5, $0.15 \mathrm{M} \mathrm{NaCl}$, $0.1 \%$ Tween 20). The pellets were resuspended with Laemmli's loading buffer, the proteins were eluted and denatured by boiling for $2 \mathrm{~min}$ and then separated by SDS-PAGE. The gel was transferred to a nitrocellulose membrane and incubated with anti-Myo9a, and Myo9b antibodies (Genway Biotech, San Diego, CA, USA).

\section{Glutathione S-transferase (GST) pull-down assays}

Pull-down assays using GST fusion proteins were performed as previously reported [30]. cDNAs encoding the C-terminal region of Myo9a, and Myo9b were cloned in $\mathrm{pET}$ 41, and the recombinant GST-Myo9a, and Myo9b fusion proteins were expressed in bacterial strain BL21 GOLD (Stratagene, La Jolla CA, USA) after induction with $0.5 \mathrm{mM}$ isopropyl thio- $\beta$-D-galactopyranoside (IPTG) (Fisher Biotech, South Australia, Australia) for $3 \mathrm{hr}$. The fusion proteins were purified using glutathione-agarose beads (Sigma-Aldrich, St. Louis, MO, USA) according to the manufacturer's protocol. Ten $\mu \mathrm{g}$ of each of the GST fusion proteins was then coupled to $50 \mu \mathrm{l}$ of glutathione-agarose beads by incubating at room temperature for $1 \mathrm{hr}$, followed by rinsing several times with PBS. The beads were pelleted by centrifugation, washed three times with the extraction buffer (1\% Triton X-100 in PBS containing $10 \mathrm{\mu g} / \mathrm{ml}$ each aprotinin, leupeptin, and pepstatin and $1 \mu \mathrm{M}$ phenylmethanesulfonyl fluoride), and once with PBS. The bound proteins were eluted from the glutathione beads with $100 \mu \mathrm{l}$ of Laemmli's load- 
ing buffer. The samples were boiled for $5 \mathrm{~min}$ and then processed for SDS-PAGE and immunoblot analysis with anti-KIF5s antibodies [26].

\section{Results}

Identification of KIF5B interacting proteins by
yeast two-hybrid screening

Previously studies reported that the C-terminal domain of KIFs bind to the cargo molecules or binding proteins $[8,26]$. To identify proteins that interacts with KIF5B, the yeast two-hybrid screening was performed. A bait construct encoding a fusion protein containing the $\mathrm{C}$-terminal region (aa 905-963) of murine KIF5B was used to screen a embryonic murine brain pJG4-5-cDNA library (Fig. 1A). In screen of $2 \times 10^{6}$ independent transformants, 5 positive clones were obtained. Plasmid DNAs encoding putative binding proteins were isolated from the X-gal positive clones. These clones were sequenced and subjected to further yeast two-hybrid retransformation assay to confirm the interactions. Two positive clones were turned out cDNA fragments containing Myo9b (Fig. 1C). The two positive Myo9b clones (clones 2, and 5) overlapped at the open reading frame (ORF) of Myo9b (Fig. 1C). Although this result was unexpected, be- cause Myo9b is a actin-based motor protein that has been implicated in the transport of membranous vesicles [17,20], a direct interaction between KIF5B and Myo9b could provide a basis for coordinating microtubule- and actin-based vesicle transport.

Myo9b is single-headed molecular motors containing a C1 $\left(\mathrm{Zn}^{2+}\right.$ binding) domain and GAP domain in the tail region (Fig. 1B) $[6,19,22,23,25,33]$. To identify the region of Myo9b required for the interaction with KIF5B, a series of deletion mutants of Myo9a and Myo9b [1] was constructed and analyzed their interactions with KIF5B using the yeast two-hybrid assay. The Rho-specific GAP domain of Myo9a and Myo9b interacted with KIF5B in the yeast two-hybrid assay (Fig. 1C). This experiment demonstrated that the minimal binding domain was located in a small region of Rho-specific GAP domain in the tail region.

To clarify whether Myo9b interacts specifically with KIF5B or with other KIFs, the C-terminal regions of KIF3B, KIF5A, KIF5B, KIF5C, KIF17, and KLC1 were constructed and the interaction of KIFs were tested for binding with Myo9b. There was no detectable binding between Myo9b and the C-terminal regions of KIF3B, KIF17, and KLC1. Myo9b interacted with the C-terminal regions of the neuronal KIF5s, KIF5A, and KIF5C in the yeast two-hybrid assay

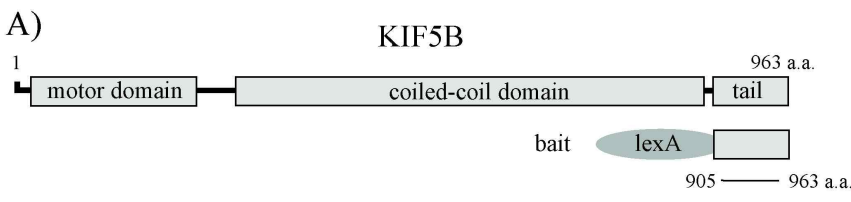

B)


Fig. 1. The GAP domain of Myo9b binds directly to KIF5B. (A) Schematic diagram illustrating the KIF5B bait construct (aa 905-963) used for the yeast two-hybrid screen. KIF5B has motor domain and coiled-coil domain. (B) Domain structure of Myo9b. Myo9b has head domain, C1 domain, and GAP domain [30]. a.a, the amino acid residue number. (C) Minimal KIF5B binding region in Myo9b. Clone 2 and 5, which were isolated from the yeast two-hybrid screen, overlapped at the C-terminal region of Myo9b. Different truncations of Myo9b and Myo9a were constructed by PCR. Several truncated forms of Myo9s were tested in the yeast two-hybrid assays for interaction with KIF5B. +++, interaction with KIF5B; -, no interaction with KIF5B. 

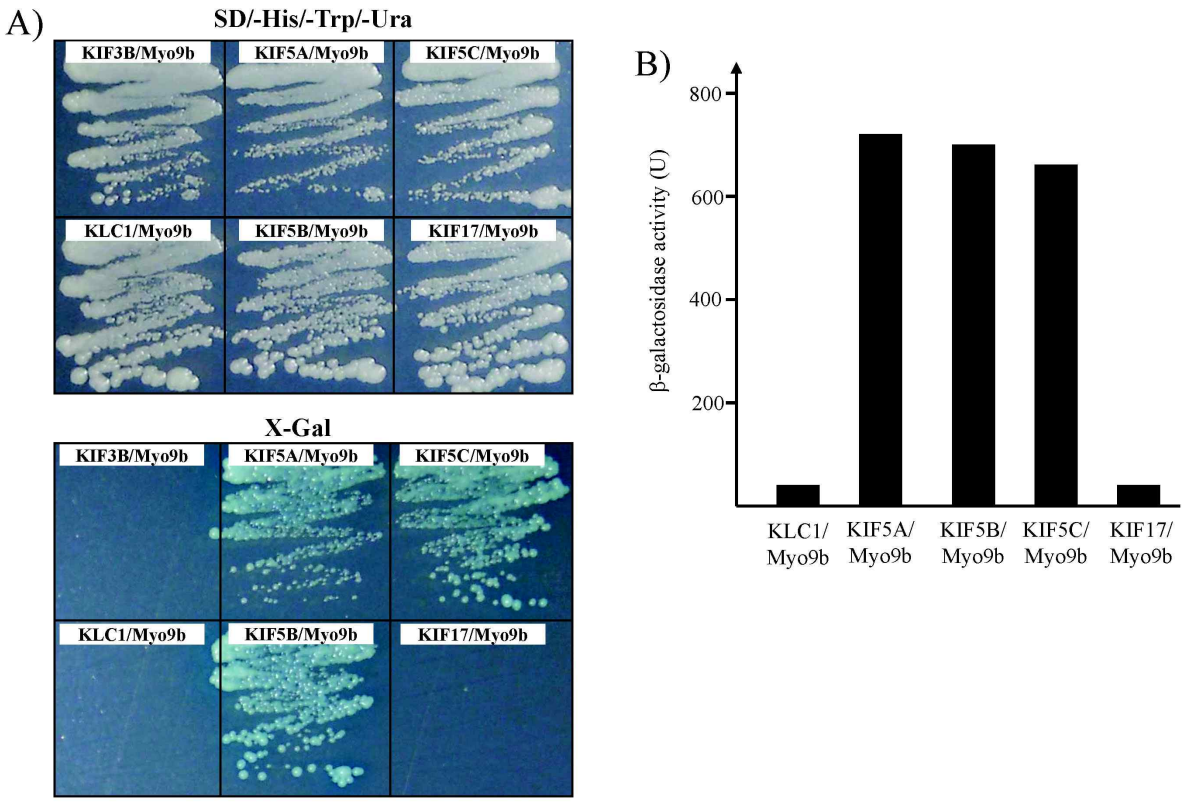

Fig. 2. Interaction between KIFs and Myo9b. (A) The C-terminal regions of each KIF protein or KLC1 were fused to the pLexA DNA binding domain. Myo9b specifically interacted with KIF5s but not with KIF3B, KIF17, and KLC. (B) The strength of interaction of KLC1, KIF5s, or KIF17 and Myo9b was examined quantitatively using $\beta$-galactosidase activity in yeast two-hybrid reporter assay.

(Fig. 2A). This result was not surprising in view of the fact that the KIF5A, KIF5B, and KIF5C share extensive similarity in their amino acid sequence $(81 \%-83 \%$ identity in the C-terminal region) [9]. These data indicate that Myo9b binds specifically to the C-terminal region of KIF5s (Fig. 2A).

To estimate the strength of the interaction between KIF5s and Myo9b, the bait plasmid of KIF5s and Myo9b was transformed to yeast and was measured the $\beta$-galactosidase activity. The interaction of KIF5s with Myo9b yielded approximately 681-712 units of $\beta$-galactosidase activity (Fig. $2 \mathrm{~B})$, reflecting a binding strength that is sufficient to mediate molecular sorting in vivo $[10,26]$.

Myo9s is associated with Kinesin-l at the protein level

To clarify whether Myo9s interacts specifically with KIF5B or whether the interaction includes other isoforms of KIF5 at the protein level, direct interaction between Myo9s and KIF5s was assayed suing a GST pull-down experiments. Recombinant GST-Myo9a or GST-Myo9b fusion proteins were expressed in E. coli. The purified GST fusion proteins are allowed to interact with mouse brain lysates. Immunoblotting analyses revealed that KIF5s interacted with GST-Myo9s, but not with GST. In addition, KLC1, which bind to the KIF5s precipitated with GST-Myo9s (Fig. $3 \mathrm{~A})$.

To address the question whether the complete Kinesin-I complex interacts with Myo9s in mouse brain, im-
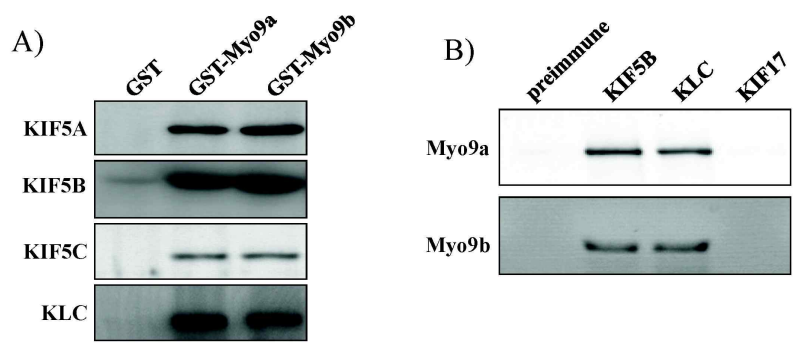

Fig. 3. Association of KIF5s with Myo9s in the GST pull-down assay and co-immunoprecipitation. (A) Proteins in the mouse brain lysate were allowed to bind to GST alone, GST-Myo9a, and GST-Myo9b fusion proteins. The elution fractions were resolved by SDS-PAGE, and Western blotting was performed using an antibody to KIF5A, KIF5B, KIF5C, or KLC. (B) Mouse brain lysates were immunoprecipitated with an anti-KIF5B antibody, anti-KIF17 antibody, anti-KLC antibody, or preimmune serum, and then the precipitates were immunoblotted with anti-Myo9a or anti-Myo9b antibodies. Input: $10 \%$ of the mouse brain lysates used for each co-immunoprecipitation assay. 
munoprecipitation analyses were performed. Lysates from mouse brain were incubated with an anti-KIF5B or anti-KLC antibodies. Protein G-agarose beads selectively precipitated the immuno-complexes, which were then subsequently separated by SDS-PAGE and immunoblotted with anti-Myo9a, and anti-Myo9b antibodies (Fig. 3B). As shown in Fig. 3B, antibody against KIF5B and KLC efficiently precipitated the Myo9s together with the Kinesin-I. These results indicate that Myo9s and Kinesin-I motor form a complex in vivo.

\section{Discussion}

Myo9s are members of the myosin superfamily protein, the molecular motors that generate the actin-based movement in neuron $[1,17,20]$. In this study, using a combination of yeast two-hybrid screen, GST pull-downs and immunoprecipitation experiments, the C-terminal regions of KIF5s was interacted directly with Myo9s. This data suggest a novel function for coordinated vesicle transport through the direct interaction of different molecular motor proteins.

Actin network is enriched at the presynaptic and postsynaptic terminal region in neuron [11,12]. The microtubule is thought to be used for long-range transport tracks whereas the actin network is proposed to be used for short-range transport [8,11]. In microtubule rich regions, KIFs are used for long-range vesicle transport but microtubules do not extend into the presynaptic and postsynaptic terminal region, and KIFs are rapidly degraded at microtubule end, indicating that vesicles may have to be transferred from microtubule track to actin track to reach at microtubule end $[7,18]$. An important question is how transport along these two tracks is coordinated. In this study, it is support the theory that these transports are coordinated in part through the direct interaction of different motor proteins from the different transport track.

Among the myosin superfamily protein, myosins are primarily involved in vesicles transport in the presynaptic and postsynaptic terminal region [8,11]. Myo2 plays important roles in migrating neurons and in growth cones. Also, Myo2 is involved in dynamic organization of actin bundles in the postsynaptic terminus region and is related to synaptic plasticity through control of spine formation $[15,24,32]$. Yeast studies have showed that Smy1 (a yeast homologue of KIF5B) can suppress the phenotype produced by mutation of Myo2 [13]. In addition, Myo2 and Smy1 co-localize to the same regions in the cell [14]. Myo5a is localized to the post- synaptic density and vesicle fractions in the brain. Several studies have shown that Myo5a is required for transport in axons and dendrites. In axons, Myo5a transports endoplasmic reticulum vesicles. Also, Myo5a is associated with mRNP complexes. In hippocampal neurons, overexpression of the cargo-binding domain of Myo5a dominant-negatively inhibited the transport of mRNP complexes into dendritic spines [8]. Myo5b, which is highly homologous to Myo5a, transports AMPA receptor-carrying recycling endosomes. Activated Myo5b triggers local exocytosis from recycling endosomes carrying AMPA receptors in dendritic spines [8,11]. Myo6 forms a complex with AP2 and SAP97 and regulates the stimulation-dependent internalization of AMPA receptors. Furthermore, Myo6 is required for the internalization of TrkB associated with BDNF, essential for the BDNF-TrkB signaling-dependent facilitation of LTP [8,11]. Myo10 is reported to be a molecular motor involved in neuronal development in growth cone [27]. Netrin receptor, essential for growth cone formation, has been identified as cargos of Myo10 [35].

Although this study did not show the interaction of KIF5B with other myosin superfamily proteins, one appealing model proposes that Kinesin-I and Myo9s bind to the same vesicle, as well as to each other, to form an integrated motor complex. The advantage of such a motor complex is that it would allow a single vesicle to be transported by multiple motors and to move on both microtubule and actin tracks [11]. Because Myo9s is directly interacted with KIF5s, axonal transport of vesicles over long distances may function in microtubule dependent transport. It may function in short-distance transport in the presynaptic terminal after the cargos are unloaded from the microtubule-KIF5s. In this report, the direct interaction between Kinesin-I and Myo9s sheds new light on the coordination mechanisms of microtubule- and actin-based transport motor.

\section{Acknowledgement}

This research was supported by Basic Science Research Program though the National Research Foundation of Korea (NRF) funded by the Ministry of Education, Science and Technology (2010-0021296).

\section{References}

1. Abouhamed, M., K. Grobe, I. V. San, S. Thelen, U. Honnert, 
M. S. Balda, K. Matter, and M. Bähler. 2009. Myosin IXa regulates epithelial differentiation and its deficiency results in hydrocephalus. Mol. Biol. Cell 20, 5074-5085.

2. Bi, G. Q., R. L. Morris, G. Liao, J. M. Alderton, J. M. Scholey, and R. A. Steinhardt. 1997. Kinesin- and myosin-driven steps of vesicle recruitment for Ca2+-regulated exocytosis. J. Cell Biol. 138, 999-1008

3. Bowman, A. B., A. Kamal, B. W. Ritchings, A. V. Philp, M. McGrail, J. G. Gindhart, and L. S. Goldstein. 2000. Kinesin-dependent axonal transport is mediated by the sunday driver (SYD) protein. Cell 103, 583-594.

4. Brady, S. T. 1985. A novel brain ATPase with properties expected for the fast axonal transport motor. Nature 317, 73-75.

5. Cai, Q., P. Y. Pan, and Z. H. Sheng. 2007. Syntabulin-kinesin-1 family member 5B-mediated axonal transport contributes to activity-dependent presynaptic assembly. J. Neurosci. 27, 7284-7296.

6. Hanley, P. J., Y. Xu, M. Kronlage, K. Grobe, P. Schön, J. Song, L. Sorokin, A. Schwab, and M. Bähler. 2010. Motorized RhoGAP myosin IXb (Myo9b) controls cell shape and motility. Proc. Natl. Acad Sci. USA 107, 12145-12150.

7. Hirokawa, N. 1998. Kinesin and dynein superfamily proteins and the mechanism of organelle transport. Science 279, 519-526.

8. Hirokawa, N., S. Niwa, and Y. Tanaka. 2010. Molecular motors in neurons: transport mechanisms and roles in brain function, development, and disease. Neuron 68, 610-638.

9. Kanai, Y., N. Dohmae, and N. Hirokawa. 2004. Kinesin transports RNA: isolation and characterization of an RNA-transporting granule. Neuron 43, 513-525.

10. Kim, S. J., C. H. Lee, H. Y. Park, S. S. Yea, W. H. Jang, S. K. Lee, Y. H. Park, O. S. Cha, I. S. Moon, and D. H. Seog. 2007. JSAP1 interacts with kinesin light chain 1 through conserved binding segments. J. Life Sci. 17, 889-895.

11. Langford, G. M. 1995. Actin- and microtubule-dependent organelle motors: interrelationships between the two motility systems. Curr. Opin. Cell Biol. 7, 82-88.

12. LeBeux, Y. J. and J. Willemot. 1975. An ultrastructural study of the microfilaments in rat brain by means of E-PTA staining and heavy meromyosin labeling. II. The synapses. Cell Tissue Res. 160, 37-68.

13. Lillie, S. H. and S. S. Brown. 1992. Suppression of a myosin defect by a kinesin-related gene. Nature 356, 358-361.

14. Lillie, S. H. and S. S. Brown. 1994. Immunofluorescence localization of the unconventional myosin, Myo2p, and the putative kinesin-related protein, Smy1p, to the same regions of polarized growth in Saccharomyces cerevisiae. J. Cell Biol. $125,825-842$.

15. Mochida, S., H. Kobayashi, Y. Matsuda, Y. Yuda, K. Muramoto, and Y. Nonomura. 1994. Myosin II is involved in transmitter release at synapses formed between rat sympathetic neurons in culture. Neuron 13, 1131-1142.

16. Muresan, Z. and V. Muresan. 2005. Coordinated transport of phosphorylated amyloid-beta precursor protein and c-Jun NH2-terminal kinase-interacting protein-1. J. Cell Biol. 171,
615-625.

17. O'Connell, C. B. and M. S. Mooseker. 2003. Native Myosin- $\mathrm{IXb}$ is a plus-, not a minus-end-directed motor. Nat. Cell Biol. 5, 171-172.

18. Okada, Y., H. Yamazaki, Y. Sekine-Aizawa, and N. Hirokawa. 1995. The neuron-specific kinesin superfamily protein KIF1A is a unique monomeric motor for anterograde axonal transport of synaptic vesicle precursors. Cell 81, 769-780.

19. Post, P. L., G. M. Bokoch, and M. S. Mooseker. 1998. Human myosin-IXb is a mechanochemically active motor and a GAP for rho. J. Cell Sci. 111, 941-950.

20. Post, P. L., M. J. Tyska, C. B. O'Connell, K. Johung, A. Hayward, and M. S. Mooseker. 2002. Myosin-IXb is a single-headed and processive motor. J. Biol. Chem 277, 11679-11683.

21. Rahman, A., D. S. Friedman, and L. S. Goldstein. 1998. Two kinesin light chain genes in mice. Identification and characterization of the encoded proteins. J. Biol. Chem 273, 15395-15403.

22. Reinhard, J., A. A. Scheel, D. Diekmann, A. Hall, C. Ruppert, M. Bähler. 1995. A novel type of myosin implicated in signalling by rho family GTPases. EMBO J. 14, 697-704.

23. Rossman, K. L., C. J. Der, and J. Sondek. 2005. GEF means go: turning on RHO GTPases with guanine nucleotide-exchange factors. Nat. Rev. Mol. Cell Biol. 6, 167-180.

24. Ryu, J., L. Liu, T. P. Wong, D. C. Wu, A. Burette, R. Weinberg, Y. T. Wang, and M. Sheng. 2006. A critical role for myosin IIb in dendritic spine morphology and synaptic function. Neuron 49, 175-182.

25. Saeki, N., H. Tokuo, and M. Ikebe. 2005. BIG1 is a binding partner of myosin $\mathrm{IXb}$ and regulates its Rho-GTPase activating protein activity. J. Biol. Chem 280, 10128-10134.

26. Setou, M., D. H. Seog, Y. Tanaka, Y. Kanai, Y. Takei, M. Kawagishi, and N. Hirokawa. 2002. Glutamate-receptor-interacting protein GRIP1 directly steers kinesin to dendrites. Nature 417, 83-87.

27. Sousa, A. D., J. S. Berg, B. W. Robertson, R. B. Meeker, and R. E. Cheney. 2006. Myo10 in brain: developmental regulation, identification of a headless isoform and dynamics in neurons. J. Cell Sci. 119, 184-194.

28. Su, Q., Q. Cai, C. Gerwin, C. L. Smith, and Z. H. Sheng. 2004. Syntabulin is a microtubule-associated protein implicated in syntaxin transport in neurons. Nat. Cell Biol. 6, 941-953.

29. Tanaka, Y., Y. Kanai, Y. Okada, S. Nonaka, S. Takeda, A. Harada, and N. Hirokawa. 1998. Targeted disruption of mouse conventional kinesin heavy chain, kif5B, results in abnormal perinuclear clustering of mitochondria. Cell 93, 1147-1158.

30. Tcherkezian, J. and N. Lamarche-Vane. 2007. Current knowledge of the large RhoGAP family of proteins. Biol. Cell 99, 67-86.

31. Vale, R. D., T. S. Reese, and M. P. Sheetz. 1985. Identification of a novel force-generating protein, kinesin, involved in microtubule-based motility. Cell 42, 39-50. 
32. Vallee, R. B., G. E. Seale, and J. W. Tsai. 2009. Emerging roles for myosin II and cytoplasmic dynein in migrating neurons and growth cones. Trends Cell Biol. 19, 347-355.

33. Wirth, J. A., K. A. Jensen, P. L. Post, W. M. Bement, and M. S. Mooseker. 1996. Human myosin-IXb, an unconventional myosin with a chimerin-like rho/rac GTPase-activating protein domain in its tail. J. Cell Sci. 109, 653-661.
34. Xia, C. H., A. Rahman, Z. Yang, and L. S. Goldstein. 1998 Chromosomal localization reveals three kinesin heavy chain genes in mouse. Genomics 52, 209-213.

35. Zhu, X. J., C. Z. Wang, P. G. Dai, Y. Xie, N. N. Song, Y. Liu, Q. S. Du, L. Mei, Y. Q. Ding, and W. C. Xiong. 2007. Myosin $\mathrm{X}$ regulates netrin receptors and functions in axonal path-finding. Nat. Cell Biol. 9, 184-192.

초록 : $\mathrm{KIF} 5 \mathrm{~s}$ 와 직접 결합하는 액틴 결합 운동단백질 Myo9s의 규명

석대현*

(인제대학교 의과대학 생화학교실)

미세소관(microtubule) 위를 이동하는 키네신은 분비소포를 이동시키는 운동단백질이다. KIF5s (KIF5A, KIF5B and $\mathrm{KIF5C)}$ 는 세포막으로 싸인 각종 세포 내 소기관과 결합하여 미세소관을 따라 목적지까지 이동시킨다는 결과 는 알려져 있지만, 어떻게 상대의 cargo를 인식하는지는 밝혀지지 않았다. 본 연구는 KIF5B의 결합 단백질을 동 정하기 위하여 효모 two-hybrid system을 사용하여 KIF5B와 특이적으로 결합하는 Myo9b을 확인하였다. Myo9b 는 액틴위를 이동하는 운동단백질로 다른 KIF5s들과도 결합함을 효모 two-hybrid assay로 확인하였다. 또한 $\mathrm{Myo9s}$ 의 GTPase 활성화 단백질(GAP) 영역은 KIF5B와 결합하는데 필수영역임을 확인하였고, 이러한 단백질간 의 결합은 Glutathione $S$-transferase (GST) pull-down assay를 통하여서도 확인하였다. 생쥐의 뇌 파쇄액에 $\mathrm{KIF} 5 \mathrm{~B}$ 들의 항체로 면역침강을 행하여 $\mathrm{Myo9s}$ 단백질을 확인한 결과, $\mathrm{KIF} 5 \mathrm{~s}$ 는 $\mathrm{Myo9s}$ 단백질과 특이적으로 함께 침강하였다. 이러한 결과들은 kinesin-I는 액틴 결합 운동단백질과 직접 결합함을 보여준다. 